'mistake' for the purposes of Blagdon Cemetery and stated that 'the correction of what can appropriately be described as a mistake within a short period does not seem to contradict the norm of the permanence of Christian burial'. The chancellor considered the similar facts in Re Christ Church, Alsager [1999] Fam 142 and considered that if the two sets of remains had had to be interred in different churchyards the petition would be stronger. Nevertheless, he found that the petition derived some strength from the fact that the deceased and his wife were buried so close together but separately, and considered that might be particularly upsetting to the family. The chancellor held that special circumstances existed and the faculty was granted. [RA]

doi:10.1017/So956618X1000061X

\title{
Maga v Roman Catholic Archdiocese of Birmingham ${ }^{\mathrm{I}}$ \\ Court of Appeal: Neuberger MR, Longmore and Smith LJJ, March 2010 Child sexual abuse - priest - vicarious liability
}

The claimant alleged that in the 1970s he had been serially sexually abused by an assistant priest in the Archdiocese of Birmingham. He appealed the decision of the High Court ([2009] EWHC 780 (QB), noted at (2009) 11 Ecc LJ 366) that the Archdiocese was not vicariously liable for the sexual abuse. The High Court had held that although the sexual abuse did take place, the priest's association with the claimant had nothing to do with the activities of the Church and was not part of evangelisation; moreover, although the Archdiocese had been negligent, it did not owe the claimant a duty of care. It was unreasonable to conclude that there was a duty to the world at large, and since there was no vicarious liability there was no duty of care. The Archdiocese cross-appealed, contending that the claim was time-barred, that the claimant had not been sexually abused and that the Archdiocese had not been negligent. The Court of Appeal allowed the claimant's appeal and dismissed the cross-appeal. Neuberger MR upheld the High Court's decision that the claim was not time-barred and that there had been sexual abuse. There was no evidence that Jack J had relied upon irrelevant evidence, ignored relevant evidence or misunderstood some evidence. However, he allowed the claimant's appeal and concluded that the abuse was 'so closely connected with [the priest's] employment' that it would be fair and just to hold the Archdiocese liable. The Archdiocese accepted that the priest should be treated as an employee for the purpose of this case; but counsel for the Archdiocese emphasised that this should not be taken as a general admission that a priest was, or was 
in the same position as, an employee of the Archdiocese. His position as a priest had given him a degree of general moral authority; his priestly functions included a duty to evangelise and he had had a special responsibility for youth work. He was able to develop his relationship with the claimant through a disco organised by him on church premises. Incidents of sexual abuse occurred at the presbytery where the priest resided because of his position. Smith LJ, though stressing that cases of this type would be fact-sensitive depending upon 'with what ostensible authority the church clothes its priests or pastors and for what legitimate purposes', held that a church would be vicariously liable for abuse where 'those legitimate purposes clothe the priest or pastor with the ostensible authority to create situations which the priest or pastor can and does then subvert for the purposes of abuse'.

The Court of Appeal upheld the High Court's judgment that there been negligence on the part of other priests in dealing with complaints against the priest. However, Neuberger MR doubted whether the High Court had been entitled to reach the conclusion that, in dealing with complaints, other priests had been negligent in not reporting them to the police and to their superiors. Jack J needed to apply the 'historic standards of 1974, rather than the contemporary standards of 2010'. Applying the standards of the time, the priest-in-charge would have been acting properly had he taken up the allegation of abuse and, having received a convincing denial, had taken the matter no further. In the event, he had been inappropriately casual in his supervision of the priest following the allegation and that negligence was causative of the claimant's loss.

The Court of Appeal held that the Archdiocese did in fact owe a duty of care to the claimant. It was misleading to regard that as a duty to the world in general, as the High Court had done; rather, it was a duty on the Church to look out for and protect young boys with whom the priest was associating after a complaint that he had sexually abused one of them. It was easy to envisage circumstances where an employer could owe, and be in breach of, a duty of care without being vicariously liable in respect of sexual abuse committed by an employee.

This case note was supplied by Russell Sandberg and is an edited version of a case summary prepared for Law and Justice. It is reproduced here with permission.

doi:10.1017/So956618X10000633

\author{
Re St Nicholas, Warwick \\ Coventry Consistory Court: Eyre Ch, April 2010 \\ Organ - replacement - hybrid - innovative technology
}

The churchwardens petitioned for a faculty for the removal of the old pipe organ and its replacement with a hybrid/combination organ. It was common ground 